\title{
Hyaluronidase inhibitory activity of extracted phenolic compounds from ultra-fine grind Saururus chinensis
}

\author{
Ki-Tae Park ${ }^{1}$, Sang-Lyong $\mathrm{Oh}^{2}$, Young-Je $\mathrm{Cho}^{2 *}$ \\ ${ }^{1}$ School of Culinary Art and Baking Technology, Dongju College University, Busan 49318, Korea \\ ${ }^{2}$ School of Food Science and Biotechnology / Food and Bio-Industry Research Institute, \\ Kyungpook National University, Daegu 41566, Korea.
}

\section{초미세 분쇄한 삼백초로부터 추출된 phenolic 화합물의 hyaluronidase 억제 효과}

\author{
박기태 $^{1} \cdot$ 오상룡 $^{2} \cdot$ 조영제 $^{2 *}$ \\ ${ }^{1}$ 동주대학교 외식조리제과계열, ${ }^{2}$ 경북대학교 식품공학부/식품생물산업연구소
}

\begin{abstract}
In this study, the anti-inflammatory effect of hyaluronidase (HAase) inhibition was determined from 92 species of oriental herbal medicine extracted with water and ethanol solvents because of their non-toxicity in the human body. The water extracts of Evodia officinalis (86.8\%), Thuja orientalis $(80.8 \%)$, Carthami semen (66.5\%), Melia azedarach (74.7\%), Siegesbeckia pubescens (61.3\%), Saururus chinensis $(49.15 \%)$ showed a relatively greater anti-inflammatory activity. The ethanol extracts of Ailanthus altissima and Saururus chinensis demonstrated the highest anti-inflammatory effect at above $90 \%$. Saururus chinensis was selected for its high anti-inflammatory effect in both water and ethanol extract. Ethanol was more effective than water and optimal extraction conditions for phenolic compounds was determined to be extraction with $50 \%$ ethanol for 12 hours. The extracts from Saururus chinensis in optimal condition showed $70 \sim 80 \%$ anti-inflammatory effect when $100 \sim 250 \mathrm{\mu g} / \mathrm{mL}$ phenolic concentration was treated. Concentration of above $500 \mu \mathrm{g} / \mathrm{mL}$ decreased the inhibitory effect. The anti-inflammatory effect and extraction yield were increased by ultra-fine grind technology, indicating that this method can be used to increase the extraction yield of phenolic compounds from medicinal plants.
\end{abstract}

Key words : anti-inflammatory activity, Saururus chinensis, extracts, phenolic compounds, ultrafine-grinding

\section{서 론}

산업이 고도로 발달함에 따라 인류가 직면하게된 환경적 요인이나 스트레스로 의한 질병이 심각한 사회 문제로 대두 됨에 따라 건강지향적인 기능성식품을 찾게 되고, 이들 기 능성 식품에 대한 관심이 증가하면서 식품소재의 천연 생리 활성물질에 대한 관심도 높아지고 있다. 식물체에 존재하 는 생리활성물질에 대한 연구의 일환으로 건강 기능성 물질

*Corresponding author. E-mail : yjcho@knu.ac.kr

Phone : 82-53-950-7755, Fax : 82-53-950-7762

Received 7 October 2015; Revised 1 December 2015; Accepted 2 December 2015.

Copyright (c) The Korean Society of Food Preservation. All rights reserved.
의 효율적인 추출을 위한 가공방법 등에 대한 기술들이 주목 받고 있다(1). 천연에 존재하는 다양한 기능성 물질들 은 빛, 산소, 수분, 온도 등의 흔히 접할 수 있는 외부요인으 로부터 영향을 받아 손상되기 쉬우며, 안정성이 저하되어 활성이 감소하게 된다. 또한 기능성 물질을 직접 섭취하였 을 때 다양한 영향인자에 의하여 용해도가 감소하게 되면 추출한 천연 생리활성물질의 활용에 막대한 영향을 받게 된다(2).

삼백초(saururus chinensis Baill)는 삼백초과에 속하는 다 년초로서 한방에서는 부종, 해독, 당뇨, 고혈압, 간염 및 황달, 해독 및 간염 등의 질환에 치료제인 약용식물로서 이용되고 있다 $(3,4)$. 삼백초 잎에는 quercetin, quercetrin, isoquercetrin, avicularin, rutin 등의 phenolic 화합물이 다량 포함되어 있어 항암 효과가 있고, 뿌리에는 약리성이 뛰어 
난 가수분해형 탄닌류가 함유되어 있어 성인병 등에 효과가 있다고 알려져 있다(4-9). 삼백초에 함유된 물질들은 간세 포 보호 활성을 가지는 것으로 보고되어 있으며(10), 항균 및 모세혈관 강화 등의 효능이 알려져 있다(11-13). 식물계 에 존재하는 생리활성성분인 phenolic 화합물은 기능성식 품, 의약품, 기능성화장품 등 많은 분야에서 활용되고 있으 며, 최근 분리 보고된 각종 천연물질들 중 상당수는 flavonoid 화합물을 포함한 phenolic 화합물임이 보고되어 있다 $(14,15)$.

초미세분쇄 및 나노 technology는 최근 식품분야에서 주 목하고 있는 첨단 기술로 생리활성물질의 용해도 증진이 나, 흡수율 증진을 목적으로 다양하게 응용할 수 있어 기존 의 식품산업이 가지고 있는 문제들을 해결할 수 있는 차세 대 핵심기술로 평가되고 있다(16). 초미세 분쇄는 식품재료 의 표면적을 극대화시켜 다양한 물질들의 용해도를 높이는 데 활용되고 있으며, 유용물질인 phenolic 화합물들의 추출 수율을 높이게 된다. 초미세분쇄는 표면적의 증대와 더불 어 모세관 효과가 나타나게 된다. 표면적 증가는 촉매반응 에 영향을 미쳐 생리활성 발현의 변화로 나타나게 되며, 모세관효과는 근본적인 물성을 변화시킴으로서 새로운 물 리적 현상들이 나타난다고 보고되어 있다 $(17,18)$. 이러한 초미세 분쇄 기술은 유용물질의 추출수율을 높이는 단순 1 차 가공처리 기술을 넘어서 한약재 등에 함유된 생리활성 물질의 용해도를 증진시켜 체내 흡수율을 높임으로서 기능 성 식품소재나 의약 소재 및 기능성 화장품소재 등 고부가 가치 소재의 가공 기법으로 활용될 수 있다.

본 연구에서는 초미세 분쇄 가공을 이용하여 phenolic 화합물의 추출수율과 생리활성을 탐색하여 선별된 시료의 고부가가치성을 높이고자 하였다.

\section{재료 및 방법}

시료의 선정

본 실험에 사용된 시료는 대구 약령시장 및 한의원에서 한약재로 사용되는 92 종을 구입하여 $40 \mathrm{mesh}$ 의 체눈을 통 과하는 분말로 만들어 시료로 사용하였다(Table 1).

\section{추출물의 제조}

물 추출물의 경우 시료 $1 \mathrm{~g}$ 에 증류수 $200 \mathrm{~mL}$ 을 넣고 액이 $100 \mathrm{~mL}$ 가 될 때까지 가열한 후 냉각하고 에탄올 추출 물은 시료에 $100 \mathrm{~mL}$ 의 $60 \%$ ethanol을 가하고 homogeniger 로 $20,000 \mathrm{rpm}$ 에서 1 분간 균질화 시킨 후 24 시간 동안 교반 추출하였으며, 추출액은 Whatman No.1 filter paper로 여과 한 후 필요에 따라 rotary vacuum evaporator(Rotavapor R-200, Buchi Labortechninik AG, Flawil, Switzerland)에서 농축하여 시료로 사용하였다.
Table 1. Phenol content and hyaluronidase inhibitory activity of extracts from oriental drugs

\begin{tabular}{|c|c|c|c|c|}
\hline \multirow{2}{*}{ Oriental drugs } & \multicolumn{2}{|c|}{$\begin{array}{l}\text { Phenolic content } \\
(\mathrm{mg} / \mathrm{g})\end{array}$} & \multicolumn{2}{|c|}{$\begin{array}{c}\text { Hyaluronidase } \\
\text { inhibitory activity } \\
(\%)\end{array}$} \\
\hline & $\begin{array}{l}\text { Water } \\
\text { extracts }\end{array}$ & $\begin{array}{l}\text { Ethanol } \\
\text { extracts }\end{array}$ & $\begin{array}{l}\text { Water } \\
\text { extracts }\end{array}$ & $\begin{array}{l}\text { Ethanol } \\
\text { extracts }\end{array}$ \\
\hline Chrysanthemum indicum $L$ & 7.4 & 7.5 & 6.76 & 30.2 \\
\hline Curcuma aromatica & 3.9 & 6.0 & - & - \\
\hline Lycium chinensis Mill & 4.3 & 3.9 & - & - \\
\hline Euryale ferox Salisb fruits & 3.4 & 1.0 & - & - \\
\hline Sophora flavescens Solander & 1.0 & 3.3 & - & - \\
\hline Glycyrthiza uralensis & 2.8 & 3.2 & - & - \\
\hline Lonicera japonica Thunberg Flower & 8.8 & 12.3 & - & - \\
\hline Platycodon grandiflorum & 1.8 & 1.8 & - & - \\
\hline Angelica koreana $L$ & 2.9 & 3.0 & - & - \\
\hline Teucrium veronicoides & 2.5 & 2.3 & - & - \\
\hline Myristica fragrans & 3.4 & 5.6 & 24.9 & 36.2 \\
\hline Maydis Stigmata & 2.9 & 2.3 & 38.2 & 43.5 \\
\hline Cinnamomum zeylanicum & 7.5 & 10.0 & - & - \\
\hline Zingiber officinale Roscoe & 2.1 & 3.0 & - & - \\
\hline Deer antler & 1.1 & 0.9 & - & - \\
\hline Vitex rotundifolia $F$ & 4.5 & 2.2 & - & - \\
\hline Equiseti Herba & 2.3 & 1.2 & - & - \\
\hline Commiphora molmol Engl. & 4.1 & 4.6 & - & - \\
\hline Liriope platyphylla & 1.3 & 1.0 & - & - \\
\hline Root of Ephedra sinica & 3.3 & 2.7 & - & - \\
\hline Root of Aucklandia lappa Decne & 4.1 & 2.6 & - & - \\
\hline Rubus coreanus Miquel & 37.1 & 36.2 & - & - \\
\hline Angelicae Dahuricae Radix & 3.0 & 1.9 & - & - \\
\hline Tribulus terrestris L. Fruits & 2.4 & 1.4 & - & - \\
\hline Silkworm & 2.8 & 1.4 & - & - \\
\hline Mentha arvensis var. piperascens & 9.8 & 4.6 & - & - \\
\hline Alumen & 5.1 & 3.4 & - & - \\
\hline tor toise shell & 0.8 & 0.6 & - & - \\
\hline Poria cocos Wolf & 0.8 & 0.8 & - & - \\
\hline Curcuma zedoaria & 1.2 & 1.1 & - & - \\
\hline Saposhnikovia divaricata $R$ & 1.4 & 1.2 & - & - \\
\hline Ginkgo biloba & 2.0 & 1.0 & - & - \\
\hline Areca Catechu L & 17.7 & 15.5 & - & - \\
\hline Magnolia kobus, Magnolia & 5.3 & 5.0 & - & - \\
\hline Saururus chinensis & 6.2 & 6.4 & 49.15 & 93.13 \\
\hline Cryptotympana pustulata Fabricus & 2.5 & 1.1 & - & - \\
\hline Bupleury radix aqueous & 1.5 & 1.2 & - & - \\
\hline Asiasarum sieboldi F. Maekawa & 2.1 & 1.9 & - & - \\
\hline Dioscorea japonica Thunberg & 2.0 & 1.6 & - & - \\
\hline
\end{tabular}


to be continued(1)

\begin{tabular}{|c|c|c|c|c|}
\hline \multirow[t]{2}{*}{ Oriental drugs } & \multicolumn{2}{|c|}{ Phenolic content $(\mathrm{mg} / \mathrm{g})$} & \multicolumn{2}{|c|}{$\begin{array}{c}\text { Hyaluronidase } \\
\text { inhibitory activity } \\
(\%)\end{array}$} \\
\hline & $\begin{array}{l}\text { Water } \\
\text { extracts }\end{array}$ & $\begin{array}{l}\text { Ethanol } \\
\text { extracts }\end{array}$ & $\begin{array}{l}\text { Water } \\
\text { extracts }\end{array}$ & $\begin{array}{l}\text { Ethanol } \\
\text { extracts }\end{array}$ \\
\hline Radix preparata & 5.7 & 5.0 & - & - \\
\hline Morus alba $L$ & 1.7 & 1.5 & - & - \\
\hline Acorus gramineus & 2.4 & 2.4 & - & - \\
\hline Cornus officinalis & 0.9 & 0.9 & - & - \\
\hline Crataegus pinnatifida Bunge var & 11.6 & 12.7 & - & - \\
\hline Trogopterorum Faeces & 1.7 & 1.8 & 14.0 & 14.6 \\
\hline artemisae capillaris herba & 14.1 & 9.8 & 41.1 & 52.6 \\
\hline Sulphur & 0.9 & 0.7 & - & 5.8 \\
\hline Arctium lappa Linne & 6.0 & 5.2 & 23.6 & 36.6 \\
\hline Curcuma longa Linné & 3.5 & 5.5 & 47.2 & - \\
\hline Styrax benzoin & 0.8 & 3.1 & 13.4 & - \\
\hline Coicis Semen & 0.8 & 0.8 & 0.1 & 16.7 \\
\hline Ligustrum japonicum & 6.3 & 4.5 & 50.7 & 74.4 \\
\hline Boswellia carterii & 1.8 & 2.9 & 58.9 & - \\
\hline Panax ginseng & 1.5 & 1.5 & 17.4 & 7.2 \\
\hline Alpinia oxyphylla Miquel & 2.0 & 1.5 & 55.2 & 19.8 \\
\hline Clematis florida & 2.7 & 3.1 & 31.1 & 5.7 \\
\hline Polygonatum odoratum & 2.2 & 2.4 & 3.6 & 13.3 \\
\hline Evodia officinalis & 16.9 & 15.8 & 86.8 & 70.0 \\
\hline Schisandra chinensis Baillon & 3.1 & 2.6 & 68.8 & 0.4 \\
\hline Bambusae Caulis & 3.2 & 3.0 & 18.5 & 28.0 \\
\hline Ailanthus altissima & 2.4 & 2.0 & 14.1 & 93.2 \\
\hline Kochia scoparia & 3.7 & 4.8 & - & - \\
\hline Lycium chinens & 2.1 & 1.9 & 11.6 & 15.6 \\
\hline Bombyx mori & 4.6 & 1.5 & - & 75.3 \\
\hline Loranthus Tanakae Franchet & 2.3 & 2.1 & 18.2 & 56.2 \\
\hline Poncirus Fructus & 4.2 & 3.4 & 27.2 & 7.4 \\
\hline Polyporus umbellatus & 1.4 & 1.0 & - & 35.6 \\
\hline Fraxinus thynchophylla & 5.5 & 5.0 & 3.7 & 21.9 \\
\hline Aconitum pseudolaeve & 5.7 & 4.5 & 52.1 & 62.0 \\
\hline Cnidium officinale & 2.8 & 3.0 & 43.8 & 79.6 \\
\hline Raphanus sativus $L$. & 2.3 & 2.7 & - & - \\
\hline Phragmites communis Trinius & 1.8 & 1.7 & - & - \\
\hline Angelica gigas Nakai & 3.1 & 2.3 & - & - \\
\hline Zizyphus jujuba Mill & 6.5 & 8.3 & - & - \\
\hline Trichosanthes kirilowi & 1.6 & 1.3 & 0.2 & 8.3 \\
\hline Melia azedarach & 2.9 & 2.4 & 74.7 & 4.1 \\
\hline Thuja orientalis & 6.8 & 8.1 & 80.8 & 62.4 \\
\hline Asparagus cochinchinensis & 1.7 & 1.7 & 5.5 & 11.6 \\
\hline Citrus unshiu & 6.2 & 6.1 & 27.3 & 3.2 \\
\hline
\end{tabular}

to be continued(2)

\begin{tabular}{|c|c|c|c|c|}
\hline \multirow[t]{2}{*}{ Oriental drugs } & \multicolumn{2}{|c|}{ Phenolic content (mg/g) } & \multicolumn{2}{|c|}{$\begin{array}{c}\text { Hyaluronidase } \\
\text { inhibitory activity } \\
(\%)\end{array}$} \\
\hline & $\begin{array}{l}\text { Water } \\
\text { extracts }\end{array}$ & $\begin{array}{l}\text { Ethanol } \\
\text { extracts }\end{array}$ & $\begin{array}{l}\text { Water } \\
\text { extracts }\end{array}$ & $\begin{array}{l}\text { Ethanol } \\
\text { extracts }\end{array}$ \\
\hline Pioer longum & 2.4 & 3.9 & 33.2 & 14.1 \\
\hline Siegesbeckia pubescens & 8.1 & 7.0 & 61.3 & 83.4 \\
\hline Armeniacae Semen & 1.7 & 4.4 & 4 & 89.1 \\
\hline Prunella vulgaris & 3.4 & 3.4 & 50.4 & 70.4 \\
\hline Kalopanax pictus & 3.9 & 4.0 & - & 83.0 \\
\hline Piper nigrum & 3.2 & 3.8 & 34.5 & 82.4 \\
\hline Polygonatum falcatum $A$ Gray & 3.0 & 3.1 & - & 93.6 \\
\hline Polygonum multiflorum & 1.9 & 1.5 & 18.7 & 50.4 \\
\hline Astragalus membranaceus & 2.1 & 2.1 & 11.6 & 57.5 \\
\hline Cuscuta chinensis & 2.0 & 1.7 & 16.6 & 28.8 \\
\hline Stichopus japonicus & 1.3 & 0.8 & - & 46.7 \\
\hline carthami semen & 2.3 & 2.3 & 66.5 & 76.1 \\
\hline Scrophularia buergeriana & 3.6 & 3.3 & 29.1 & 34.1 \\
\hline Sepia esculenta & 0.9 & 0.8 & - & 33.0 \\
\hline Talcum & 0.8 & 0.8 & - & 23.9 \\
\hline
\end{tabular}

Phenol성 화합물의 정량

Phenol성 화합물의 정량은 Folin과 Davis 방법(19)에 준 하여 측정하였다. 추출물 $2 \mathrm{~mL}$ 에 $5 \% \mathrm{Na}_{2} \mathrm{CO}_{3}$ 용액 240 $\mu \mathrm{L}$ 를 가하고 발색시약으로 $1 \mathrm{~N}$ folin ciocalteu reagent 120 $\mu \mathrm{L}$ 를 넣고 잘 섞어준 뒤, 10 분간 방치하여 발색시키고, 흡광 도 $725 \mathrm{~nm}$ 서 1시간 이내에 $\mathrm{OD}$ 를 측정하여 gallic acid를 이용한 표준곡선으로 양을 환산하였다.

추출물의 염증억제(hyaluronidase 억제)효과 측정

Hyaluronidase(HAase) 저해활성 측정은 sodium- hyaluronic acid(HA)로부터 형성된 N-acetylglucosamine을 glucoxazoline 유도체로 변형시킨 후 $p$-dimethylamino benzaldehyde (DMAB)로 발색시켜 흡광도를 측정하여 효소 활성을 측정 하였다(20). 0.1 M acetate buffer(pH 3.5)에 녹인 HAase(7,900 unit $/ \mathrm{mL}) 0.05 \mathrm{~mL}$ 와 시료용액 $0.1 \mathrm{~mL}$ 를 혼합하여 $37^{\circ}$ 에서 20 분간 배양한 다음 $12.5 \mathrm{mM} \mathrm{CaCl} 20.1 \mathrm{~mL}$ 를 가하고 혼합 후 다시 20분간 배양 하였다. 기질로서 $0.1 \mathrm{M}$ acetate buffer(pH 3.5)에 녹인 $\mathrm{HA}(12 \mathrm{mg} / \mathrm{mL})$ 를 첨가하여 다시 40 분간 배양하여 $0.4 \mathrm{~N}$ potassium tetraborate $0.1 \mathrm{~mL}$ 및 0.4 $\mathrm{N} \mathrm{NaOH}$ 용액을 $0.1 \mathrm{~mL}$ 반응 혼합물에 첨가하여 3 분 동안 수욕상에서 가열한 후 완전히 냉각시켰다. 냉각 시킨 반응 물에 발색제로 $\mathrm{DMAB}$ 시약 $3 \mathrm{~mL}$ 을 가하여 $37^{\circ} \mathrm{C}$ 에서 20 분 간 배양한 다음 $585 \mathrm{~nm}$ 에서 흡광도를 측정하여 저해활성 (\%)은 (1-시료첨가군의 흡광도/무첨가군의 흡광도) $\times 100$ 으 로 산출하였다. 
미쇄 분쇄와 초미세 분쇄 시료의 제조

본 실험에서 사용된 시료는 $45^{\circ} \mathrm{C}$ 건조기에서 열풍 건조 시킨 삼백초잎을 한국생명공학연구원 정읍 분원에 있는 $10 \mathrm{~L}$ 용량의 초미세 분쇄 장치(MKFS10-1, Koen $21 \mathrm{Co}$, Ansan, Korea)를 이용하여 시간당 $20 \mathrm{~kg}$ 의 grinding 속도로 fine grinding(125 $\mathrm{mm}$ ISO mesh size, ASTM 140 mesh : 초과 사이즈)과 ultrafine grinding(125 $\mu \mathrm{m}$ ISO mesh size, ASTM $140 \mathrm{mesh}$ : 미만 사이즈)으로 나누어 분쇄 사용하였다.

\section{통계분석}

성적은 평균 \pm 표준오차로 표기하였다. 각 군간의 차이는 t-test를 사용하여 평가하였으며 $95 \%$ 유의수준을 인정하 였다.

\section{결과 및 고찰}

약용작물 추출물의 페놀함량 및 hyaluronidase억제 활성 측정

식물에 존재하는 많은 phytochemical 중 폴리페놀 화합물 이나 플라보노이드류는 여러 가지 식물에 널리 분포되어 있으며 천연 항산화제로써 작용할 수 있다는 여러 연구들이 행해져 왔다. 이에 따라 본 연구에서는 92종의 한약재로부 터 물과 $60 \%$ ethanol을 용매로 하여 phenol성 물질을 추출하 여 총 페놀함량을 측정한 결과 Table 1 에서와 같이 물 추출 물에서는 Rubus coreanus Miquel(복분자)가 $37.1 \mathrm{mg} / \mathrm{g}$ 으로 가장 높은 함량을 나타내었으며, $60 \%$ ethanol 추출물에서 역시 복분자 추출물이 가장 높은 함량을 나타내었고 다음으 로 Evodia officinalis(오수유) 추출물이 $15.8 \mathrm{mg} / \mathrm{g}$ 으로 다른 시료에 비해 높게 나타났다. 경북지방에 많이 재배되고 있 는 Saururus chinensis(삼백초)의 경우 각각 물과 $60 \%$ ethanol 추출물에서 각각 $6.2 \mathrm{mg} / \mathrm{g}$ 과 $6.4 \mathrm{mg} / \mathrm{g}$ 의 phenolic 성분이 함유된 것으로 나타났다. 실험에 사용한 시료 대부 분은 물과 $60 \%$ ethanol 추출물의 함량이 비슷하거나 $60 \%$ ethanol 추출물이 조금 높은 페놀함량을 나타내었다.

$\mathrm{HA}$ 는 고분자 다당으로 진피층의 섬유아세포에서 산출되 어, 표피, 진피에 주요한 세포외 매트릭스로 glucuronic acid와 glucosamine이 반족해서 연결된 점액성 moucopolysaccharide 이다. 그리고, 염증 형성의 중요 요소인 macrophage의 phagocytic ability를 저해하는 한편, HA 분해 산물 혹은 저분자 HA는 상처 치유과정에서 inflammation, fibrosism, collagen deposition을 증가시키는 것으로 고분자 $\mathrm{HA}$ 의 분 해효소인 HAase의 저해에 의해 HA의 고분자 형태를 유지 하게 함으로서 항염증 효과를 기대할 수 있다. 따라서 in vitro test로서 HAase 활성을 측정함으로서 항염증효과를 탐색하게 되고, 항염증활성을 이용한 항염증제제나 아토피 관련 제품에 적용이 가능하게 될 것이다 $(21,22)$. 여러 가지
한약재 추출물을 이용하여 HAase 저해 활성을 측정한 결과 Table 2에서와 같이 Evodia officinalis(오수유) 물 추출물이 $86.8 \%$ 의 저해 활성으로 가장 높게 나타났으며, Thuja orientalis(측백엽, $80.8 \%$ ), Carthami semen(홍화자, 66.5\%), Melia azedarach(천련자, 74.7\%), Siegesbeckia pubescens(희 렴, $61.3 \%$ ), Saururus chinensis(삼백초, $49.15 \%$ ) 등이 비교 적 높게 나타났다. $60 \%$ ethanol 추출물에서는 $93.2 \%$ 와 93.13\%의 저해활성을 나타낸 Ailanthus altissima(저근백피) 와 Saururus chinensis(삼백초) 추출물이 가장 높게 나타났 고, Siegesbeckia pubescens(희렴), Armeniacae Semen(행인), Kalopanax pictus(해동피), Piper nigrum(호초), Polygonatum falcatum A Gray(황정) 추출물이 $80 \%$ 이상의 높은 항염증 활성을 나타내었다. 여러 가지 한약재 추출물을 이용하여 항염증 억제 효과를 조사한 결과 삼백초가 물 추출물과 ethanol 추출물 모두에서 높은 항염증활성을 나타내어 염증 억제를 위한 시료로 선발되었다.

Table 2. Content of phenolic compounds and inflammatory activity in extracts from Saururus chinensis by grinding technique

\begin{tabular}{ccccc}
\hline \multirow{2}{*}{ Grinding technique } & \multicolumn{2}{c}{ Phenolic content $(\mathrm{mg} / \mathrm{g})$} & \multicolumn{2}{c}{ Hyaluronidase inhibition $(\%)$} \\
\cline { 2 - 5 } & Water extracts & $\begin{array}{c}\text { Ethanol } \\
\text { extracts }\end{array}$ & Water extracts & $\begin{array}{c}\text { Ethanol } \\
\text { extracts }\end{array}$ \\
\hline Normal grinding & $6.2 \pm 1.2^{1)}$ & $6.4 \pm 1.6$ & $41.2 \pm 2.1$ & $73.1 \pm 1.1$ \\
Fine grinding & $11.0 \pm 1.6^{*}$ & $13.8 \pm 1.1^{*}$ & $45.4 \pm 1.5$ & $76.1 \pm 2.3$ \\
Ultrafine grinding & $12.9 \pm 0.7^{*}$ & $15.7 \pm 2.0^{*}$ & $51.2 \pm 2.2^{*}$ & $92.4 \pm 1.0^{*}$ \\
\hline
\end{tabular}

${ }^{1)}$ The data were expressed as the mean $\pm \mathrm{SD}(\mathrm{n}=6),{ }^{*} \mathrm{p}<0.05$.

삼백초로부터 phenolic 화합물의 최적 분리조건 규명

삼백초 추출물의 고형분에 포함된 phenolic 화합물의 함 량은 매우 낮게 나타났으며(Fig. 1-A), phenolic 화합물 함량 이 낮은 고형분의 생리활성 역시 매우 낮은 수준으로 나타 났다(Fig. 1-B). 따라서 생리활성은 삼백초 추출물에 함유되 어있는 phenolic 화합물에 의해 효과가 좌우 될 것으로 판단 되었다. 위의 결과에 근거하여 삼백초로부터 생리활성에 관여하는 phenolic 화합물을 추출하기 위하여 선별된 삼백 초의 유효성분을 보다 효율적으로 추출할 방안을 확립하기 위하여 인체에 유해하지 않은 용매로 물과 에탄올을 선택하 여 추출 시간, 용매의 농도에 따라 추출되는 phenolic 화합물 의 함량을 측정하였다.

식물체에 존재하는 phenolic 화합물은 식물의 방어기작 으로 생산되는 2 차 대사산물의 한 종류이며, 분자구조 내에 존재하는 phenolic hydroxyl기에 의해 단백질 등 거대 분자 들과 결합하는 특성을 나타내어 다양한 생리 기능을 가진다 고 보고되어 있다 $(23,24)$. Ethanol 농도에 따른 phenolic 화합 물의 함량을 측정한 결과 Fig. 2-A에서와 같이 $10 \%$ ethanol 에서 $11.3 \mathrm{mg} / \mathrm{g}, 30 \%$ ethanol에서 $12.8 \mathrm{mg} / \mathrm{g}, 50 \%$ ethanol에 서 $15.3 \mathrm{mg} / \mathrm{g}$ 으로 ethanol의 함량에 따라 지속적으로 증가하 


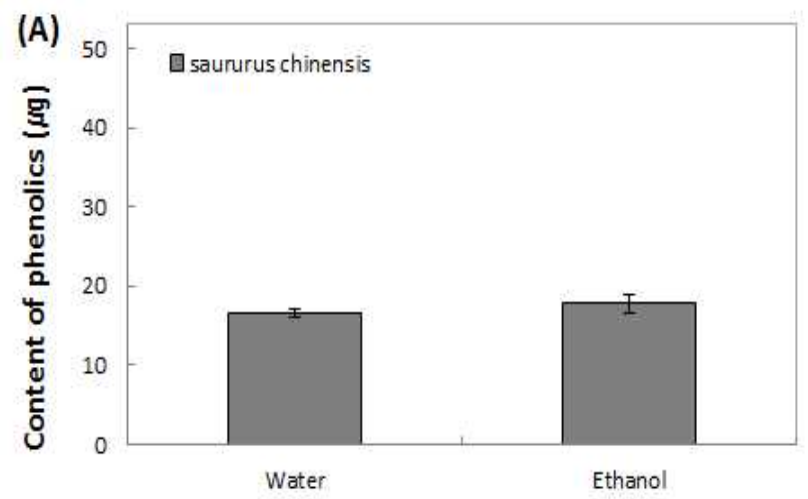

Extracted solid (1 mg)

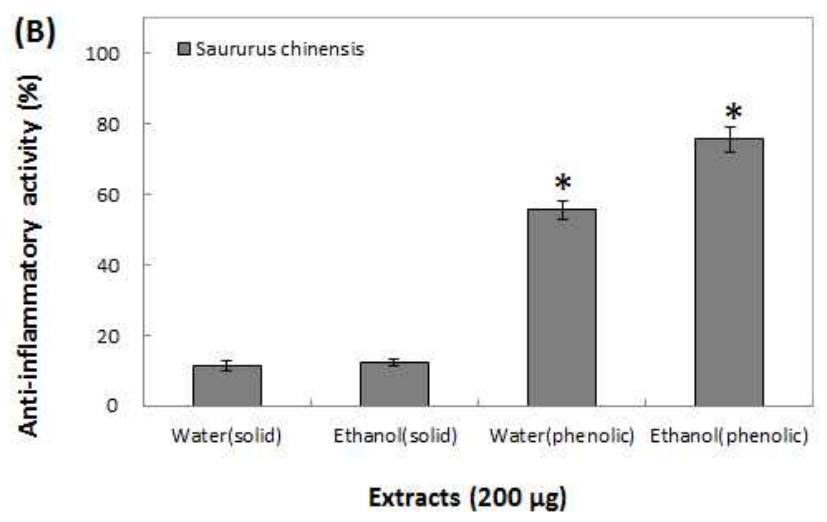

Fig. 1. The content of phenolic compound in extracted solid (A) and anti-inflammatory activity of extracted solid and phenolic (B) from Saururus chinensis.

The data were expressed as the mean $\pm \mathrm{SD}(\mathrm{n}=6),{ }^{*} \mathrm{p}<0.05$.

다 $60 \%$ 이상의 ethanol 농도에서는 추출 수율이 오히려 감소하는 경향을 나타내었으며, 물을 용매로 쓰는 것 보다 ethanol $50 \%$ 로 추출하는 것이 보다 효율적인 것으로 나타났 다. $50 \%$ ethanol을 용매로 하여 삼백초를 일정 시간 단위로 phenolic 화합물을 추출하고 함량을 측정한 결과 Fig. 2-B에 서와 같이 12 시간 추출하였을 때 $13.04 \mathrm{mg} / \mathrm{g}$ 으로 가장 높은 추출 수율을 나타내었으며, 12 시간 이후는 추출수율이 비 슷한 수치로 유지됨을 알 수 있었다. 따라서 삼백초의 생리 활성 물질의 추출을 위한 최적조건은 $50 \%$ ethanol을 용매로 하여 12 시간 추출하는 것이 최적이었다.

삼백초 추출물의 첨가농도에 따른 염증억제 효과 발현 삼백초 추출물 첨가농도에 따른 염증억제 활성은 Fig. 3 에서와 같이 추출물을 $100 \sim 250 \mu \mathrm{g} / \mathrm{mL}$ phenolic 화합물 농도로 첨가했을 때 70 80\%의 염증 억제 활성(HAase 억제 효과)이 높게 나타났으며, $250 \mu \mathrm{g} / \mathrm{mL}$ 까지 첨가 농도가 높아 지면서 억제 활성은 농도 의존적으로 증가하는 것으로 확인 되었으나, $500 \mathrm{\mu g} / \mathrm{mL}$ 이상의 농도로 phenolic 화합물 첨가 시 억제활성이 오히려 감소하는 경향을 나타내었는데, 추 출물의 사용 농도를 $250 \mathrm{\mu g} / \mathrm{mL}$ 이하로 사용하여야 경제적
으로 유리하며 그 이상의 농도에서는 오히려 약효가 떨어 져, 경제적 사용 기준점을 제시해주는 자료로 활용할 수 있을 것으로 판단하였다.
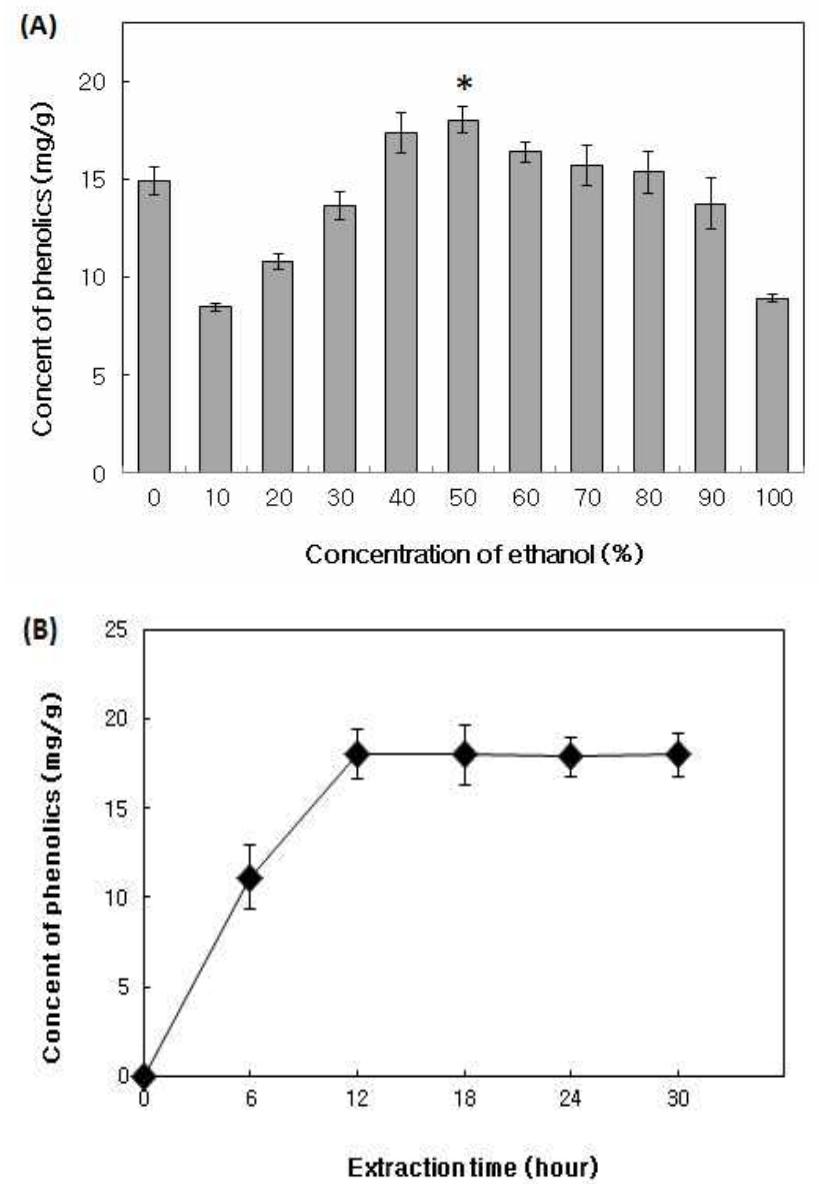

Fig. 2. Effect of ethanol concentration and extraction time on extraction of phenolic compound from Saururus chinensis. The data were expressed as the mean $\pm \mathrm{SD}(\mathrm{n}=6),{ }^{*} \mathrm{p}<0.05$.

초미세 분쇄에 의한 phenolic 화합물의 용출량 및 염증억 제 활성의 변화

초미세 분쇄 기술은 해당 물질의 표면적을 극대화시킴으 로 분해가 어려운 물질들의 용해도를 높이는 장점이 있다. 또한 상대적으로 유용성 물질인 penolic 화합물의 추출 수 율을 높이고 추출 또한 용이하게 된다. 이러한 초미세 분쇄 기술은 1 차 가공처리 기술을 넘어서 기존 한약재의 용해도 를 증진시킴으로(체내 흡수율 증가) 기능성 식품소재나 식 의약 소재 등 고부가 가치소재로 전환을 기대할 수 있다 (25).

본 연구에서는 초미세 분쇄 가공 기술을 이용하여 phenolic 화합물의 추출수율과 생리활성을 탐색하여 선별 된 시료의 고부가가치성을 높이고자 하였다. 선별된 시료 중 항염증 활성 효과가 뛰어난 삼백초를 미세분쇄와 초미세 분쇄하여 각각의 phenolic 화합물의 추출수율과 염증억제 
활성을 비교하였다. 그 결과 Table 2에서와 같이 물보다 에탄올을 이용하는 것이 효과적이며, 초미세 분쇄를 하였 을 때 추출 수율이 더욱 증가하는 것을 알 수 있었다(26). Cho 등(27)이 보고한 홍삼의 입자 크기에 대한 추출수율이 원형삼에 비해 10 40 mesh로 분쇄 하였을 때, 1.56 배 높아 진다는 보고와 같이 입자가 작아질수록 추출수율이 높아짐 을 알 수 있었다.

미세분쇄와 초미세분쇄의 유용성 물질 추출에 대한 비교 로서 삼백초 물 추출물과 $50 \% \mathrm{EtOH}$ 추출물의 염증 억제효 과를 비교한 결과 Table 2 에서와 같이 분쇄하지 시료에 비해 초미쇄 분쇄한 시료에서 항염증 활성이 증가하는 것을 알 수 있었다. 앞에서 추출수율에 미친 초 미쇄 분쇄의 결과 에서 알 수 있듯이 초미세 분쇄에 의해 생리활성물질들이 더 많이 용출되어 나온 결과로 판단되었다. 분쇄 종류별로 비교하면 물 추출물의 경우 미세보다 초미세 분쇄 삼백초가 $15.8 \%$ 정도 HAase 저해활성이 우수하였으며, $50 \% \mathrm{EtOH}$ 추출물의 경우도 초미세 분쇄 시료가 $16.3 \%$ 가량 우수한 HAase 저해활성을 가졌으며, 삼백초 물추출물 보다 $\mathrm{EtOH}$ 추출물이 $20 \%$ 이상 우수한 HAase 저해활성을 가졌다. 이는 $\mathrm{HeO}$ 등(28)이 아토피 유도군 실험에 감시료를 초미세 처리 하여 사용하였을 때 미세분쇄하지 않은 시료에 비해 보다 우수한 효과를 나타내었다는 결과와 유사한 결과를 보임을 알 수 있었다.

따라서 약용식물 중에서 삼백초 추출물의 HAase 활성억 제 효과가 우수하였으며, HAase 활성과 연관된 항염증 효 과도 우수하리라 추측되었으며, 초미세 분쇄 기술을 삼백 초에 적용하였을 때 HAase 억제 물질에 대한 추출수율의 증가 효과를 기대할 수 있었다. 또한 초미세 분쇄 기술은 다양한 한약재로부터 생리활성물질 추출수율의 증가를 목 적으로 적용할 수 있는 기술로 개발이 가능할 것으로 판단 되었다.

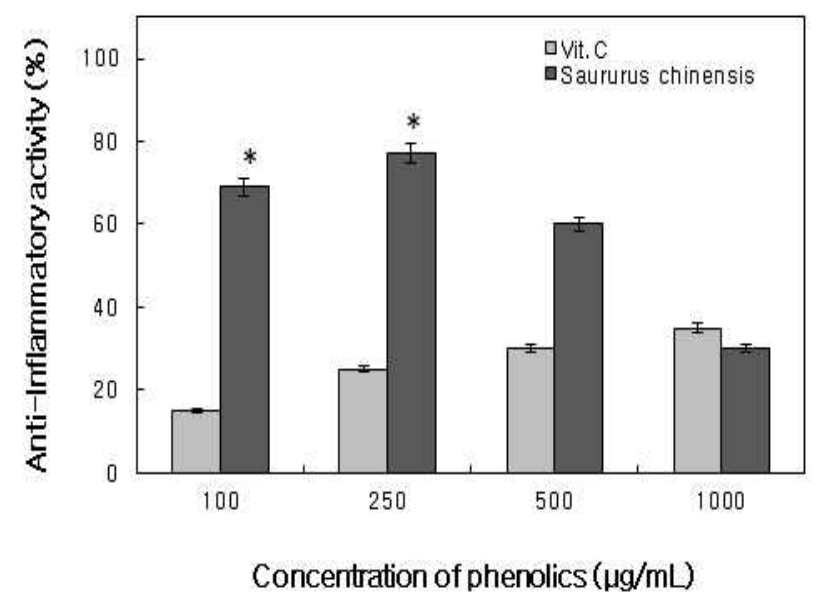

Fig. 3. Inflammation inhibition effect based on phenol concentration.

The data were expressed as the mean $\pm \mathrm{SD}(\mathrm{n}=6),{ }^{*} \mathrm{p}<0.05$.

\section{요 약}

본 연구에서 92 종의 한약재로부터 물과 ethanol을 용매 추출물에 대하여 HAase의 저해에 의한 항염증 효과를 측정 한 결과 물 추출물에서는 E. officinalis(86.8\%), T. orientalis (80.8\%), C. semen(66.5\%), M. azedarach(74.7\%), S. pubescen (61.3\%), S. chinensis(49.15\%) 등이 높게 나타났다. Ethanol 추출물에서는 $A$ altissima와 S. chinensis 추출물이 $90 \%$ 이상의 높은 항염증 활성을 나타내었다. 이들 중 물과 에탄올 추출물에서 모두 항염증 활성이 높게 측정된 $S$. chinensis가 선발되었다. 선별된 삼백초의 유효성분을 보다 효율적으로 추출할 방안을 확립하기 위하여 인체에 유해하 지 않은 용매로 물과 ethanol을 선택하여 추출 최적조건을 살펴보았다. Phenolic 성분의 추출을 위한 최적조건은 $50 \%$ ethanol을 사용하여 12시간 추출이 최적이었다. Phenolic 성분의 추출을 위해서는 ethanol이 물보다 더 효율적이었 다. 최적조건에서 추출된 삼백초 추출물의 염증억제 활성 은 100 250 $\mathrm{\mu g} / \mathrm{mL}$ phenolic 농도로 첨가했을 때 70 80\%의 염증 억제 효과를 나타내었으나, $500 \mu \mathrm{g} / \mathrm{mL}$ 이상의 농도로 첨가 시 오히려 염증 억제활성이 감소하는 경향을 나타내었 다. 삼백초를 초미세 분쇄 하였을 때 추출 수율과 염증억제 활성이 증가하는 것을 확인하였다. 따라서 초미세 분쇄 기 술은 한약재로부터 생리활성물질 추출수율의 증가를 목적 으로 적용할 수 있는 기술로 개발이 가능할 것으로 판단되 었다.

\section{감사의글}

이 논문은 지식경제부에서 2009년부터 2012년까지 시행 한 지역산업전략기획기술개발사업의 결과이며, 연구개발 비 지원에 감사드립니다.

\section{References}

1. Ko SH (2008) Nanodispension and nanoparticle using food-grade materials. J Food Sci Ind, 41, 25-31

2. Bell LN (2001) Stability testing of nutraceuticals and functional foods. In : Handbook of nutraceuticals and functional foods. Wildman REC (Editor), CRC press, New York, p 501-516

3. Kwon SA (1999) A second series about Saururus chinensis and Houttuynia cordata Thunberg. J Korean Orient Drug, 2, 18-20

4. Park JH, Lee CK (2000) The encyclopedia of medicinal plants. Shinilbooks Publishing Co., Seoul, p 202-203 
5. Lee YN (2002) Flora of Korea. Kyo-Hak Publishing Co. Ltd., Seoul, p 218-219

6. Kwon SA (1999) A second series about Saururus chinensis and Houttuynia cordata Thunberg. J Korean Oriental Drug, 3, 28-31

7. Choe KH (1999) A study on chemical composition and anti-microbial activity of Saururaceae growing in Korea. $\mathrm{Ph}$ D Thesis, Kyung Hee University, Korea

8. A society for Korea medicinal botany (2001) Medicinal botany. Hakchang publishing Co., Seoul, p 176

9. Choe KH, Yoon CH, Kwon SJ (1994) A study on chemical composition of Saururaceac growing in Korean on flavonoid constituents of Saururus chinensis. J Korean Soc Anal Sci, 7, 11-15

10. Kwon SH (1996) The isolation of anti-hepatotoxic constituents from Saururus chinensis. MS Thesis, Seoul National University, Korea, p 40

11. Lee ST, Lee YH, Choi YJ. Lee YH, Choi JS, Heo JS (2001) Yield and bioactive component on different compost amounts and culture method of Saururus chinensis Baill. Korean J Med Crop Sci, 9, 220-224

12. Lee ST, Park JM, Lee HK, Kim MB, Cho JS, Heo JS (2000) Component comparison in different growth stages and organs of Saururus chinensis Bail. Korean J Med Crop Sci, 8, 312-318

13. Kim BH, Song WS (2000) The dyeability and antimicrobial activity of Saururus chinensis (I). J Korean I lomc Economics, 38, 1-9

14. Lim DK, Choi U, Shin DH (1996) Antioxidative activity of ethanol extract from Korean medicinal plants. Korean J Food Sci Technol, 28, 83-89

15. Park SS, Yu KH, Min TJ (1998) Antioxidative activity of ethanol extract from fruiting bodies of mushrooms. Korean J Mycol, 26, 69-77

16. Lopez-Rubino A, Gavara R, Lagaron JM (2006) Bioactive packaging: turning foods into healthier foods through biomaterials. Trends Food Sci Technol, 17, 567-575

17. Kim KH, Lee IH, Lee HS, Park JK (2003) R\&D trend and information analysis of nanoparticles. Prosp Ind
Chem, 6, 46-61

18. Kim CS, Kim CS, Kim HI (2009) Physicochemical properties of non-waxy rice flour affected by grinding methods and steeping times. J Korean Soc Food Sci Nutr, 38, 1076-1083

19. Folin O, Denis W (1912) On phosphotungsticphosphomolybdic compounds as color reagents. J Biol Chem, 12, 239-243

20. Reissig JL, Stominger JL, Leloir LF (1995) A modified colorimetric method for the estimation of $\mathrm{N}$-acetylamino sugars. J Biol Chem, 217, 959-966

21. Cho YJ (2014) Biological activity of extracts from Chrysanthemum incidicum Linne by ultrafine grinding, J Korean Soc Food Sci Nutr, 43, 110-117

22. Kim JS, Lee JY, Park KT, An BJ, Lee SH, Cho YJ (2013) The biological activity from Prunella vulgaris extracts. Korean J Food Preserv, 20, 234-241

23. Choi WH, Park WY, Hwang BY, Oh GJ, Kang SJ, Lee KS, Ro JS (1998) Phenolic compounds from the stem bark of Cornus walteri Wnager. Korean J Pharmacogn, 29, 217-223

24. Choi HS, Kim MG, Shin JJ, Pack JM, Lee JS (2003) The antioxidant activities of the some commercial teas. J Korean Soc Food Sci Nutr, 32, 723-727

25. Yoon WB (2011) Effects of particle size and high pressure process on the extraction yield of oil compounds from soybean powder using hexane and supercritical fluid. Food Eng Progr, 15, 203-208

26. Cho YJ (2014) Antioxidant, angiotensin converting enzyme and xanthin oxidase inhibitory activity of extracts from Saururus chinensis leaves by ultrafine grinding. Korean J Food Preserv, 21, 75-81

27. Cho CW, Kim SW, Rho JH, Rhee YK, Kim KT (2008) Extraction characteristics of saponin and acidic polysaccharide based on the red ginseng particle size. J Ginseng Res, 32, 179-186

28. Heo JC, Lee KY, Lee BG, Choi SY, Lee SH, Lee SH (2010) Anti-allergic activities of ultra-fine powder from persimmon. Korean J Food Preserv, 17, 145-150 